\title{
Physicochemical and thermal characteristics of sugarcane straw and its cellulignin
}

\author{
Eliana Vieira Canettieri ${ }^{1}$ (D) Vinícius Pereira da Silva ${ }^{2} \cdot$ Turíbio Gomes Soares Neto $^{2}$. \\ Andrés Felipe Hernández-Pérez ${ }^{3} \cdot$ Debora Danielle Virgínio da Silva $^{4} \cdot$ Kelly Johana Dussán ${ }^{4}$. \\ Maria das Graças Almeida Felipe ${ }^{3} \cdot$ João Andrade de Carvalho Jr. ${ }^{1}$
}

Received: 20 December 2017 / Accepted: 28 July 2018/Published online: 10 August 2018

(C) The Brazilian Society of Mechanical Sciences and Engineering 2018

\begin{abstract}
Combustion of biomass is considered to be a source of atmospheric pollution and, therefore, is one of the important sources of $\mathrm{CO}_{2}$ emission. This paper discusses the burning of sugarcane straw and its cellulignin in laboratory tests to determine the characteristics and emission factors, of this combustion process. Elemental, chemical composition and thermogravimetric analyses were performed for both samples. Carbon contents for sugarcane straw and its cellulignin were estimated, and the values found were $45.69 \%$ and $44.28 \%$, respectively. Higher heating values (HHV) were determined by experimental methods with a calorimetric bomb and were estimated by theoretical equations. The best results were obtained when only the lignin's content was considered. During the experimental tests to determine HHVs, cellulignin did not burn completely, while straw burned completely. This could be because cellulignin contains more ashes, resulting in more residual ash after burning. Pollutant emission of $\mathrm{CO}_{2}, \mathrm{CO}, \mathrm{NO}$ and $\mathrm{UHC}$ was evaluated in the flaming and smoldering combustion phases. NO concentrations were not presented because they were less than $10 \mathrm{ppm}$. The average theoretical and experimental emission factors for $\mathrm{CO}_{2}$ were analyzed. $\mathrm{CO}_{2}$ emissions factors found for sugarcane straw and their cellulignin were $1316 \pm 83.6$ and $1275 \pm 105 \mathrm{~g} \mathrm{~kg}^{-1}$ of dry burned biomass, respectively. The evaluated parameters are useful to incorporate these materials into a future biorefinery.
\end{abstract}

Keywords Biomass $\cdot$ Emissions factor $\cdot$ Thermochemical conversion $\cdot$ Biorefinery $\cdot$ Energy

\section{Introduction}

Technical Editor: Fernando Marcelo Pereira.

Eliana Vieira Canettieri

eliana.canettieri@unesp.br

1 Department of Energy, São Paulo State University (UNESP), Campus of Guaratinguetá, Guaratinguetá, SP 12516-410, Brazil

2 Associated Laboratory of Combustion and Propulsion, National Institute of Space Research (INPE),

Cachoeira Paulista, SP 12630-970, Brazil

3 Biotechnology Department, Engineering School of Lorena EEL, São Paulo University (USP), Lorena, SP 12602-810, Brazil

4 Biochemistry and Chemical Technology Department, Chemistry Institute, São Paulo State University (UNESP), Araraquara, SP 14800-900, Brazil
To meet the constantly increasing demand for energy and raw materials, environmental preservation, and economic independence, governments and organizations throughout the world aim to diversify the energy grid and invest in renewable alternative energy sources, especially considering that fossil fuels are finite resources and produce pollution. The thermochemical conversion of biomass is one of the technologies recommended to reduce the use of fossil fuels and meet the demand for sustainable growth [1-5]. Brazil is in a privileged position in this case; it is a worldwide reference in sustainable energy production from biomass and reduced rates of $\mathrm{CO}_{2}$ release by replacing gasoline with ethanol and fuel oil with bagasse. In February 2010, the United States Environmental Protection Agency (EPA) classified ethanol produced from sugarcane as an advanced biofuel, stating that it produces $61 \%$ less greenhouse gases than gasoline. 
In Brazil, the forecast for area planted with cane for alcohol production in the 2017-2018 harvest is 8.84 million hectares; the production of sugarcane in the 2017-2018 harvest is estimated to be 647.7 million tons [6]. Each ton of sugarcane processed generated around $140 \mathrm{~kg}$ of straw and $140 \mathrm{~kg}$ of bagasse in dry weight, which is, 12 tons of straw and 12 tons of bagasse per hectare [7]. One ton of straw is the equivalent of $1.28 \mathrm{PBE}$ (petroleum barrel equivalents), so not using this lignocellulosic material would be wasting energy [8].

Straw produced during the harvest of sugarcane could be a source of energy in Brazil because the harvest is moving toward complete automation without burning [9]. This makes the straw available for use in energy production. The traditional manual harvest method was followed by burning the straw. This causes serious environmental problems including $\mathrm{CO}_{2}$ emissions, which is a risk factor for human health. It also creates the risk of losing control of the fire in the field and causing fires in adjacent areas. To increase productivity and develop sustainable practices, many plants have adopted automated harvest. Using cane straw and bagasse in direct combustion provides almost negligible $\mathrm{CO}_{2}$ emissions balance because the resulting emissions are absorbed and fixed by the plant during the growth processes [10].

Brazil is one of the countries that most uses renewable energy; $92 \%$ of the electricity consumed is renewable: $85 \%$ is generated by water and $7 \%$ by biomass [11]. According to the Brazilian National Electric Energy Agency (ANEEL), [12] the main technological pathways used to obtain electric energy from biomass are: steam cycle with back pressure turbines, steam cycle with condensation and extraction turbines, and combined cycle integrated with biomass gasification. These pathways require biomass conversion in intermediate production that will be used in a driving machine, which produces the mechanical energy that activates the electricity generator. Biomass is considered to be one of the main options for diversifying the energy grid linked with reducing dependence on fossil fuels.

One of the critical points of burning sugarcane straw is the release greenhouse gases and other pollutant gases, mainly carbon dioxide gas $\left(\mathrm{CO}_{2}\right)$, carbon monoxide $(\mathrm{CO})$, nitrous oxide $\left(\mathrm{N}_{2} \mathrm{O}\right)$, methane $\left(\mathrm{CH}_{4}\right)$ and ozone $\left(\mathrm{O}_{3}\right)$, in addition to smoke and soot. For these reasons, research on the use of cane straw as a fuel must be developed to place this resource in the sustainable category, which will also generate economic interest.

Straw can be used in a biorefinery to produce secondgeneration ethanol and/or to obtain combustion energy directly in boilers [13-16]. Its direct participation in ethanol production has also been evaluated; studies have been published that evaluate pretreatment, enzymatic hydrolysis, and recovered sugar fermentation technologies [17-22]. In addition, different studies have estimated potential increases in ethanol and/or electricity production in plants without increasing the area cultivated with cane by adding the contribution of cane straw [14, 15, 23, 24].

Little is understood about emissions processes and the databases covering emissions factors of important trace gases from industrial burning are still very limited. The objective of this work was to determine the emission factors of the main pollutants resulting from the burning of sugarcane straw and its cellulignin. The physicochemical and thermal characteristics of these biomasses were also investigated through two techniques: analytical chemical analysis and TGA/DTG.

\section{Materials and methods}

\subsection{Raw materials and acid hydrolysis}

The raw material for this study was sugarcane straw and its cellulignin (the solid fraction obtained after acid hydrolysis pretreatment of sugarcane straw). Sugarcane straw was provided by Usina Pederneiras, located in Tietê, São Paulo, Brazil.

Dilute acid hydrolysis of the sugarcane straw was performed in a 40- $\mathrm{L}$ reactor. The sugarcane straw was mixed with $1.0 \%(\mathrm{w} / \mathrm{v}) \mathrm{H}_{2} \mathrm{SO}_{4}$ at $1: 10$ solid/liquid ratio at $121{ }^{\circ} \mathrm{C}$ for $20 \mathrm{~min}$. After hydrolysis, the hemicellulosic hydrolyzate was cooled, recovered, and stored at $4{ }^{\circ} \mathrm{C}$ for use in the production of xylitol [17, 18]. The solid fraction obtained (cellulignin) from this pretreatment process was used in the present study.

\subsection{Elemental composition}

Elemental analysis on dry biomass was determined on an EA-1108 CHNS-O analyzer, Carlo Erba Instruments (represented by Fisons Instruments). The preweighed sample (2 mg) was placed in the oven at $1020^{\circ} \mathrm{C}$, where pure $\mathrm{O}_{2}$ was injected in a flash combustion process. The reaction products $\mathrm{CO}_{2}, \mathrm{H}_{2} \mathrm{O}, \mathrm{N}_{2}$ and $\mathrm{SO}_{2}$ were quantitatively determined by gas chromatography, where the elements were detected (thermal conductivity detector) and the signals were recorded.

\subsection{Higher heating value (HHV) analysis}

Tests to determine the higher heating value (HHV) of the sample were performed in a IKA-Werke model C2000 digital calorimetric bomb connected to an IKA-Werke model KV600 water supply chiller. A sample mass of 
approximately $1.0000 \pm 0.0001 \mathrm{~g}$ was employed, and analyses were carried out in triplicate.

In addition to the determination by calorimeter, the HHVs were also calculated from empirical equations. Many equations have been developed to correlate higher heating value using the elemental composition of biomass. For fuel derived from biomass, $\mathrm{HHV}\left(\mathrm{MJ} \mathrm{kg}^{-1}\right)$ can be estimated from the levels of $\mathrm{C}, \mathrm{H}, \mathrm{O}$, and $\mathrm{N}[25,26]$ determined by elemental analysis using the Eq. (1).

$$
\begin{aligned}
\mathrm{HHV}= & (33.5 \mathrm{C}+142.3 \mathrm{H}-15.4 \mathrm{O}-14.5 \mathrm{~N}) \\
& \times 10^{-2}
\end{aligned}
$$

in which $\mathrm{C}$ is carbon content, $\mathrm{H}$ is hydrogen content, $\mathrm{O}$ is oxygen content, and $\mathrm{N}$ is nitrogen content. $\mathrm{HHV}$ is given in $\mathrm{MJ} \mathrm{kg}^{-1}$ or $\mathrm{kJ} \mathrm{g}^{-1}$.

Equation (2) includes lignin level in the model [25, 26]:

$\mathrm{HHV}=0.0889(\mathrm{~L})+16.8218$

in which $\mathrm{L}$ is lignin content (\% dry weight) and HHV is given in $\mathrm{MJ} \mathrm{kg}^{-1}$.

A relationship between the contents of HHV, lignin and extractives from the straw and was the model represented by the multiple regression [25, 26] as the Eq. (3).

$\mathrm{HHV}=14.3377+0.1228(\mathrm{~L})+0.1353(\mathrm{Ext})$

in which $\mathrm{L}$ is lignin content (\% dry weight), Ext is extractives content ( $\%$ dry weight), and HHV given in $\mathrm{MJ} \mathrm{kg}^{-1}$.

\subsection{Chemical characterization: analytical chemical analysis}

All samples were ground in a knife mill to the size of a 20 mesh $(0.841 \mathrm{~mm})$ particle. The chemical composition of whole sugarcane straw and its cellulignin (solid fraction obtained after acid hydrolysis from sugarcane straw) was determined following the methodology of Gouveia [27].

\subsection{Thermal characterization: TGA/DTG}

Thermogravimetric experiments were performed in an SDT-Q600 TA Instruments simultaneous thermal calorimeter, and results were analyzed using TA Advantage 5008TGA software. Four commercial products were used as standards to represent the components of the biomass: xylan from beech wood (X4252 Sigma-Aldrich); cellulose (Sigma-Sigmacell Type 100 9004-34-6); cellulose (AvicelType PH102); and lignin semiconcentrated using steam explosion (Usina Vale do Rosário). The pyrolysis experiments were conducted by exposing approximately $10 \mathrm{mg}$ samples to an atmosphere of inert $\mathrm{He}$ gas at a flow of $80 \mathrm{~mL} \mathrm{~min}^{-1}$ and a heating rate of $10{ }^{\circ} \mathrm{C} \min ^{-1}$ from room temperature to $1000{ }^{\circ} \mathrm{C}$.

\subsection{Determination of emissions factors for carbon dioxide $\left(\mathrm{CO}_{2}\right)$, carbon monoxide (CO), nitrogen oxide (NO) and unburned hydrocarbon (UHC) using specific analyzers}

The biomasses were placed in a burner made up of a grill supported on a cone with a small fan at the bottom to blow air when biomass was being burned (Fig. 1). The system follows the guidelines for biomass combustion in an equipment specified by Soares Neto et al. [28] and França et al. [29]. In this system, air is entrained by the combustion process and its flow rate is not controlled. This device was placed over a $1 \mathrm{~m}^{2}$ tray located inside a container. This tray is supported on a scale to register loss of mass during burning. Above the tray, there is a hood attached to a chimney containing temperature sensors, probes for gas collection, and differential and absolute pressure sensors. To guarantee air flow through the chimney, an axial exhaust is used. It is installed inside the chimney above the point at which measurements are taken [4, 28, 29]. For the laboratory burning experiments, there were a total of four repetitions for sugarcane straw and six repetitions for

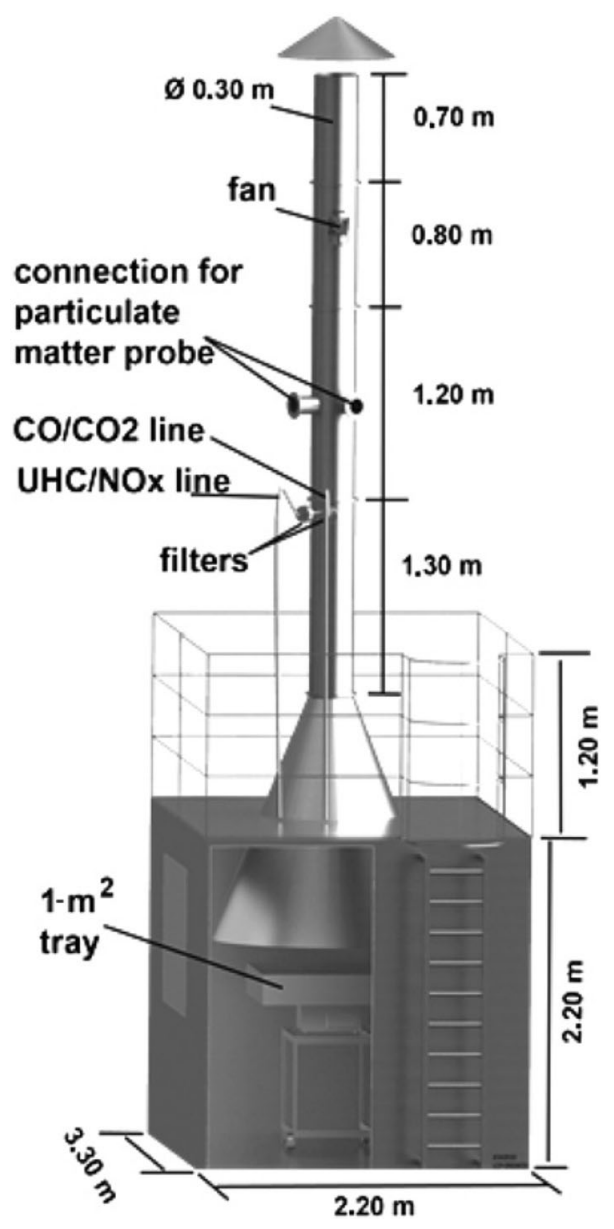

Fig. 1 Experimental setup for combustion tests [28, 29] 
cellulignin; approximately $300 \mathrm{~g}$ of each sample was used per repetition.

All the experimental data were registered using a data acquisition system that monitored the following variables: carbon monoxide $(\mathrm{CO})$, carbon dioxide $\left(\mathrm{CO}_{2}\right)$, nitrogen oxide (NO), and unburned hydrocarbon (UHC) concentrations; mass loss during combustion; volume flow rate of chimney gases; temperature of chimney gases; and temperature near the flame. Table 1 shows the models and scales of the gas analyzers.

The temperature of the gases was determined by means of a type $\mathrm{K}$ thermocouple that performs well in the range of 100 to $1200{ }^{\circ} \mathrm{C}$. The temperatures in the experiments were within this range. The pressure within the chimney was determined by a classic L-shaped Pitot tube. To collect the gases emitted during combustion, probes were installed inside the chimney: one to analyze NO and UHC concentrations and two to analyze $\mathrm{CO}_{2}$ and $\mathrm{CO}$ concentrations. The other tube with samples for NO and UHC analysis was connected in another circuit that contained a water tank to cool the sample to $3{ }^{\circ} \mathrm{C}$, removing water from the sample by condensation. The tubing that carried samples for the $\mathrm{CO}$ and $\mathrm{CO}_{2}$ analyzer was connected to the circuit that contained the trap submerged in an isopropyl alcohol bath at $-35^{\circ} \mathrm{C}$ to remove tar and water. To register the data obtained during the experiments, an application in LabView software was used. The average emission factor of a species $X$, or $\mathrm{FE}_{X}$, was calculated using the Eq. (4):

$\mathrm{EF}_{X}=\frac{V_{\text {total }}}{m_{\text {fuel }, D}} \frac{[]_{X} M_{X}}{V_{X}} \quad\left(\frac{g_{X}}{k g_{\text {dry fuel }}}\right)$

where $V_{\text {total }}$ is the total volume of gas flow that passes through the chimney during the test $\left(\mathrm{m}^{3}\right),[]_{X}$ is the average concentration of species $X$ (non-dimensional), $M_{x}$ is the molecular mass of species $X\left(\mathrm{~g} \mathrm{~mole}^{-1}\right), m_{\mathrm{fuel}}$ is the amount of fuel consumed in dry weight $(\mathrm{kg})$, and $V_{x}$ is the molar volume of gas at standard temperature and pressure $(\mathrm{STP})\left(=0.0224 \mathrm{~m}^{3}\right)$.

Table 1 Model and scale of the analyzers

\begin{tabular}{lll}
\hline Analyzer & Type & Scale \\
\hline Group 1 & & \\
Rosemount analytical model 400A & $\mathrm{UHC}$ & $1-1000 \mathrm{ppm}$ \\
Rosemount analytical model 951A & $\mathrm{NO}$ & $0-100 \mathrm{ppm}$ \\
Group 2 & & \\
Rosemount analytical model 880A & $\mathrm{CO}$ & $0-1.000 \mathrm{ppm}$ \\
Rosemount analytical model 880A & $\mathrm{CO}$ & $0-5 \%$ \\
Rosemount analytical model 880A & $\mathrm{CO}_{2}$ & $0-10.000 \mathrm{ppm}$ \\
Rosemount analytical model 755A & $\mathrm{O}_{2}$ & $0-100 \%$ \\
VEB Junkalordestau-DDR Permolyt2 & $\mathrm{O}_{2}$ & $0-23 \%$ \\
\hline
\end{tabular}

Emissions factor, $\mathrm{FE}_{x}$, for chemical species $\mathrm{CO}_{2}, \mathrm{CO}$, $\mathrm{NO}$ and UHC, in $\mathrm{g} \mathrm{kg}^{-1}$ (grams of species $X$ per kg of dry burned biomass) was calculated for the specific period that combustion occurred. For the calculations, the term []$_{X}$, which represents the average concentration of gas $X$ during the period studied, was determined by the average concentration registered in the experiments subtracted from the average background value determined for each experiment and measured before the experiment.

To obtain the total volume of gas $X$ that was emitted throughout the experiment, the average concentration registered in ppmv [ $]_{X}$ was multiplied by the total volume of the gaseous sample that flowed through the chimney throughout the experiment. This volume is indicated by the term $V_{\text {Total chimney }}$ and indicates the normalized volume at standard temperature and pressure (STP) conditions, which is the flow measured by Digiflux.j. This normalization is needed due to the temperature variation of the chimney gases and a consequent alteration in their densities. The flow computer Digiflux.j includes this normalization and compensation for flow density variation in its calculations. If this were not the case, there would be an error on the order of $15 \%$ in the volume flow calculation. This flow was integrated throughout the duration of the experiment from the beginning, which was the instant of biomass ignition. This leads to the normalized volume total chimney, the value which is used to calculate the emissions factor.

With the total volume that a specific gas flows during the experiment, simply divide the value for the molar volume of the gas $\left(V_{x\left(1 \mathrm{~mol}, 1 \mathrm{~atm}, 0{ }^{\circ} \mathrm{C}\right)}\right)$ by the temperature at which the volume was normalized to determine the number of moles of gas that was emitted in the experiment. Multiplying this number of moles by the molar mass of the gas $\left(M_{X}\right)$ gives the mass of the gas that was emitted during the experiment. This value divided by the mass of biomass consumed ( $\left.m_{\text {fuel (dry weight) }}\right)$ provides the emissions factor value. The mass consumed was corrected for dry weight.

The instantaneous EF was also investigated using two tests, one with straw and the other with cellulignin. In this case, the mass variation in the balance $(-\mathrm{dm} / \mathrm{dt})$ was computed and used in Eq. (4) with the instantaneous volume flow rate. The fuel moisture content also must be accounted for. The resulting Eq. (5) is:

$\mathrm{EF}_{X, \text { inst }}=\frac{V}{(1-M)\left(-\frac{\mathrm{d} m}{\mathrm{~d} t}\right)} \frac{[]_{X, \text { inst }} M_{X}}{V_{X}} \quad\left(\frac{g_{X}}{k g_{\text {dryfuel }}}\right)$

where $V \mathrm{~m}^{3} \mathrm{~s}^{-1}$ is the product gas volume flow rate, []$_{X \text {,inst }}$ is the instantaneous concentration of the component $X$ (non-dimensional), $M$ is the fuel moisture content in terms of mass of water per total mass of fuel (non-dimensional), and $-\mathrm{d} m / \mathrm{d} t$ is the instantaneous burn rate of 
fuel $\left(\mathrm{kg} \mathrm{s}^{-1}\right) . M_{X}$ and $V_{x}$ have been previously defined in the description of Eq. (4).

\section{Results and discussion}

\subsection{Physicochemical characterization of sugarcane straw and its cellulignin}

The main characteristics of sugarcane straw and its cellulignin for the elemental analysis and chemical composition are shown in Table 2. Várhegyi et al. [30] carried out an elemental analysis of four types of biomass (cornstalk, rice husk, sorghum straw and wheat straw) and ash content varied between 4 and $16 \%$, higher values than those found in the present study, which were between 1.47 and $1.75 \%$. These authors analyzed the composition of ashes and verified the presence of $\mathrm{Ca}, \mathrm{Mg}$ and $\mathrm{S}$ and greater amounts of $\mathrm{K}$ and Si. C, H, O and $\mathrm{N}$ values determined were similar to those shown in Table 2 for cane straw and its cellulignin.

Rocha et al. [31] analyzed seventy types of cane bagasse to evaluate possible differences in elemental composition and the relationship between these components. These authors showed that the carbon level of different types of biomass was approximately $45 \%$ with a standard deviation of $1 \%$, values that are near those encountered in this study for cane straw and cellulignin. The carbon level of biomass is approximately $45 \%$, while charcoal is approximately $60 \%$ or more carbon [32] The main advantage of thermal conversion of solid lignocellulose biomass is that $\mathrm{CO}_{2}$ emissions from biomass combustion are considered "neutral" for the greenhouse effect due to the process of photosynthesis, which reduces the amount of $\mathrm{CO}_{2}$ in the air and redirects it into the sugar in the material [31].

Table 2 Results of elemental analysis and chemical composition of sugarcane straw and straw cellulignin

\begin{tabular}{lll}
\hline & $\begin{array}{l}\text { Sugarcane } \\
\text { straw }\end{array}$ & $\begin{array}{l}\text { Sugarcane straw } \\
\text { cellulignin }\end{array}$ \\
\hline Elemental analysis & & \\
C (\%) & 45.69 & 44.28 \\
H (\%) & 5.80 & 5.67 \\
O (\%) & 48.38 & 49.73 \\
N (\%) & 0.13 & 0.32 \\
Chemical composition & & \\
Extractives $(\%)$ & $8.91 \pm 0.3$ & $2.81 \pm 0.1$ \\
Cellulose (\%) & $31.46 \pm 0.4$ & $48.30 \pm 0.1$ \\
Hemicellulose $(\%)$ & $27.03 \pm 0.1$ & $9.31 \pm 0.2$ \\
Lignin $(\%)$ & $31.14 \pm 0.1$ & $37.84 \pm 0.2$ \\
Ashes $(\%)$ & $1.47 \pm 0.1$ & $1.75 \pm 0.1$ \\
\hline
\end{tabular}

\subsection{Higher heating values (HHV) analysis}

The experimental HHV of sugarcane straw and its cellulignin were determined with a calorimetric bomb. The results for higher heating values of the samples of sugarcane straw and its cellulignin were $17.38 \pm 0.28 \mathrm{MJ} \mathrm{kg}^{-1}$ and $17.40 \pm 0.13 \mathrm{MJ} \mathrm{kg}^{-1}$, respectively. During the tests to determine HHV, the cellulignin did not burn completely, while straw burned completely. This behavior can be attributed to the existence of higher ash content in cellulignin, resulting in more residual ash after burning. HHV were similar for both biomasses, with an average of 17.39 $\mathrm{MJ} \mathrm{kg}^{-1}$. Vamvuka and Zografos [33] characterized different types of agricultural waste (green olive pits, green olive wood, citrus wood, and vines) and reported that these materials are composed of a low level of ash (1.5-4.0\%), a low level of sulfur (0.03-0.08\%), and HHV varying from 16.74 to $20.93 \mathrm{MJ} \mathrm{kg}^{-1}$, values that are comparable to low-quality charcoal. Their net higher heating value varied between 14.65 and $18.84 \mathrm{MJ} \mathrm{kg}^{-1}$, considerably higher than those of most low-quality charcoal.

The $\mathrm{C}, \mathrm{H}, \mathrm{O}$, and $\mathrm{N}$ values in Table 2 were inserted into Eq. (1) to estimate HHV values for cane straw, and its cellulignin of $15.27 \mathrm{MJ} \mathrm{kg}^{-1}$, and $15.20 \mathrm{MJ} \mathrm{kg}^{-1}$, respectively. These values are within the limits encountered in published studies. Demirbas [25] reported that the variation of higher heating values of different species of wood was less than $15 \%$ (dry weight). Considering that the energy released from natural fuel is related to the oxidation state in which carbon atoms generally dominate and the variation of the levels of hydrogen is insignificant, a linear relationship between HHV and carbon level is encountered for different species of wood. HHVs of lignocellulosics fuel increase with the increase in lignin levels and are correlated with lignin level [32]. This means that the HHV of lignocelluloses fuel strongly depends on lignin content. HHV of samples that do not contain extracts reflects the HHV in cellulose and hemicellulose relative to lignin [32]. Demirbas [26] reported that cellulose and hemicellulose (holocellulose) have an $\mathrm{HHV}$ of $18.60 \mathrm{MJ} \mathrm{kg}^{-1}$, while lignin has an HHV from 23.26 to $26.58 \mathrm{MJ} \mathrm{kg}^{-1}$.

Cellulignins are free of extracts because they are obtained after acid hydrolysis, which removes the extracts. Using the values in Table 2, HHV can be empirically calculated related to lignin through Eq. (2). HHV values obtained from total lignin were 19.59 and $20.19 \mathrm{MJ} \mathrm{kg}^{-1}$ for cane straw and straw cellulignin, respectively. Telmo and Lousada [34] determined the HHV of 17 wood fuels and correlated with their klason lignina (L) and extractive contents (Ext). These authors concluded that the HHV of a lignocellulosic material depend strongly on its chemical 
composition, more specifically than lignin and extractive contents, and that greater HHV improve burning.

In the present study, sugarcane straw presented less lignin contents, but a higher extractive content than straw cellulignin (Table 2), and when subjected to combustion resulted in $\mathrm{CO}_{2}, \mathrm{NO}_{X}$ and $\mathrm{UHC}$ emission factors larger than that of cellulignin from sugarcane straw (Table 2). However, cellulignin with higher lignin content and less extractives yielded a greater $\mathrm{CO}$ emission factor than straw. Using Eq. (3) to determine the HHV of straw cane and its cellulignin, similar values were found, 19.37 and 19.36 $\mathrm{MJ} \mathrm{kg}^{-1}$, respectively.

Comparing all the results using the calorimetric bomb and the three theoretical equations (Sect. 2.3), the best results were when only the lignińs content was considered [Eq. (2)]. The lignin content is determinant in the higher heating value of lignocellulosic materials.

\subsection{Characterization of sugarcane straw and its cellulignin by thermal analysis}

To study the decomposition of the samples, the thermal analysis technique was used. Thermal analyses are auxiliary, practice and quick methods to determine combustion and/or pyrolysis characteristics of a solid material [35]. A lot of research has used thermal analysis techniques to investigate the pyrolysis and/or combustion process for different lignocellulose materials, such as cane bagasse, rice straw, elephant grass, and mixtures of different grasses with bituminous coal, as well as the respective decomposition reaction kinetics [36-41].

Initially, thermogravimetric analysis (TGA) and differential thermal analysis (DTG) assays were performed with the samples used as standard, Xilana (hemicellulose), Cellulose Sigma, Cellulose Avicel and Lignin, which are used to represent the main components of biomass. The loss of mass variation during the pyrolysis process is shown in the thermogravimetric (TG) curve. For Xilan (hemicellulose) the first derivative of this curve, known as the derived thermogravimetric curve (DTG) shows the rate of mass variation. The most significant loss of mass took place between 200 and $350{ }^{\circ} \mathrm{C}$ and the DTG curve has two maximum peaks at $240{ }^{\circ} \mathrm{C}$ and $290{ }^{\circ} \mathrm{C}$, respectively. Hemicellulose is an amorphous polymer mainly made of five sugar monomers: D-xilose, L-arabinose, D-galactose, Dglucose, and D-manose, of which D-xilose is the most abundant [42-44]. Commercial xilan was used as a standard sample for hemicellulose in these experiments and can contain two different types of saccharides. Similar results were reported by Zhou et al. [45].

Two samples of pure commercial cellulose were used in this study: Sigma and Avicel cellulose. Both cellulose samples have similar mass loss properties and the temperature range of this thermal degradation reaction was similar: $250-400{ }^{\circ} \mathrm{C}$ and $200-400{ }^{\circ} \mathrm{C}$, respectively. The cellulose molecule is a polymer with a very long chain. It is crystalline and made up of glucose units without branches.

Semiconcentrated lignin samples that had been isolated by the steam explosion process (Usina Vale do Rosário) were used as standards in the TGA tests. The peaks of the cellulose and hemicellulose DTG curves were more defined; lignin had broader peaks on the DTG curves. Lignin began to decompose at about the same temperature as hemicellulose and had a gradual loss of mass up to $1000{ }^{\circ} \mathrm{C}$. The loss of mass took place mainly from 180 to $600{ }^{\circ} \mathrm{C}$ and maximum peak temperature was $340{ }^{\circ} \mathrm{C}$. The method used to isolate constitutive lignin from lignocellulosic material influenced the determination of the nature and structure of the lignin obtained [45]. Many methods can be used to isolate lignin with a greater or lesser degree of purity. The alkaline method produces a lignin with less sulfur contamination, while considerable amounts of sulfonate groups are incorporated into the lignin during the sulfite process. The best isolation method is the one that can break the polymer into smaller fragments, contributing to greater thermal stability and more like lignin in origin. The lignin used as a standard in this study was isolated by the steam explosion method.

Figure 2 shows the thermogravimetric (TGA) and thermogravimetric (DTG) curves derived from pyrolysis of cane straw (a) and its cellulignin (b) in a He atmosphere at a heating rate of $10{ }^{\circ} \mathrm{C} \mathrm{min}{ }^{-1}$ with a flow of $80 \mathrm{~mL} \mathrm{~min}{ }^{-1}$. These curves show that this pyrolysis process basically develops in three main events. In the first event, the oven temperature gradually increases and the mass of the samples reduces due to the evaporation of residual water and then remains constant. The second begins with the removal and pyrolysis of the volatile material; the TG curve becomes more accentuated and in this temperature range and the greatest loss of mass occurs. Finally, the TG curve becomes attenuated because most of the volatile material has already been removed and the sample is completely pyrolyzed until the only thing that is left is carbonized waste and the mass becomes constant.

Figure $2 \mathrm{a}$ shows that the first event took place between room temperature and $150{ }^{\circ} \mathrm{C}$. In this step, the biomass absorbs heat, releasing humidity in the form of steam, which has a strongly endothermal character. Between 110 and $150{ }^{\circ} \mathrm{C}$, it is thought that there are dehydration reactions involving the $\mathrm{OH}$ groups in the polysaccharide molecules. The TG and DTG curves for straw and cellulignin, at temperatures between 25 and $150{ }^{\circ} \mathrm{C}$, both had the same behavior and a loss of mass of $5.04 \%$ and $3.17 \%$, respectively. This loss of mass may be from the humidity in the sample. 

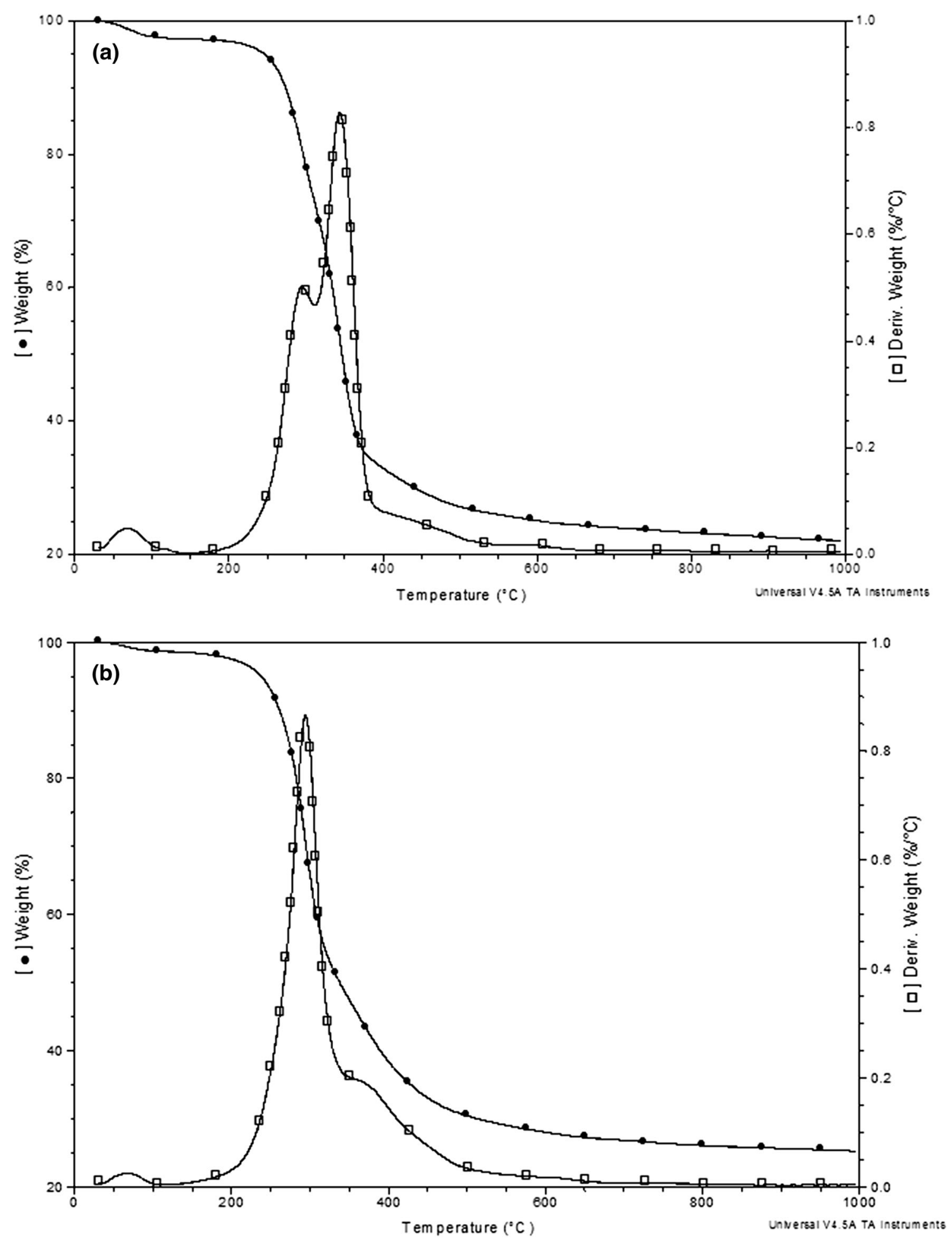

Fig. 2 TG and DTG curves obtained from SDT-Q600 TA Instruments simultaneous thermal calorimeter and TA Advantage 5008TGA software: a sugarcane straw and $\mathbf{b}$ sugarcane straw cellulignin in an inert $\mathrm{He}$ atmosphere at a heating rate of $10{ }^{\circ} \mathrm{C} \mathrm{min}{ }^{-1}$ with a flow of $80 \mathrm{~mL}$ min ${ }^{-1}$

Figure 2a also reveals that the main loss of mass took place between 200 and $400{ }^{\circ} \mathrm{C}$. In this temperature range, total degradation was $59.19 \%$ of initial mass, which has two maximum peaks, one at $280{ }^{\circ} \mathrm{C}$ and another at $340{ }^{\circ} \mathrm{C}$, similar to that found for the standard components isolated from the biomass. In this temperature range, the degradation of hemicellulose and cellulose is believed to take place; the straw contains $59.19 \%$ hemicellulose and 
cellulose. This value is similar to what was determined through the chemical analysis of straw shown in Table 2, in which the sum of hemicelluloses and cellulose results in $58.49 \%$. The DTG curve shows two events in this range, a small plateau at $200-300{ }^{\circ} \mathrm{C}$ and another at $300-400{ }^{\circ} \mathrm{C}$, around $21.84 \%$ and $37.35 \%$ loss of mass, respectively. Thus, there was probably $21.84 \%$ hemicellulose and $37.35 \%$ cellulose. Lignin is degraded more strongly beginning at $400{ }^{\circ} \mathrm{C}$ and like the straw sample, it was not totally degraded: there was $19.48 \%$ waste.

It is important to point out that in the present study, the cane straw sample initially underwent acid hydrolysis to extract the hemicellulose fraction and thus the cellulignin straw should contain all its cellulose and lignin and some residual hemicelluloses from the hydrolysis process because of solubilization of the sugars in this process.

TGA (weight loss) and DTG (weight loss rate) curves of cellulignin are shown in Fig. 2b. The TGA curve indicates that most of the degradation took place between 200 and $400{ }^{\circ} \mathrm{C}$ with a total of $56.40 \%$ mass loss and a maximum peak at $280{ }^{\circ} \mathrm{C}$. However, the DTG curve has two events, the first of $48.17 \%$ loss of mass in the $200-350{ }^{\circ} \mathrm{C}$ range and a plateau at $350-400{ }^{\circ} \mathrm{C}$ with an $8.24 \%$ loss of mass. This was similar to the DTG curves of the Avicel cellulose and Sigma cellulose standards, which occurred between 200 and $400{ }^{\circ} \mathrm{C}$. The small variation in temperature range can be attributed to the fact that Avicel and Sigma cellulose, isolated from a plant, are theoretically made up only of cellulose, unlike cellulignin, which contains cellulose, lignin and residual hemicelluloses from acid hydrolysis. Comparing these results to those encountered in the chemical analysis (Table 2) reveals that the level of cellulose was $48.30 \%$ in the chemical analysis, while in the thermal analysis it was $48.17 \%$. The degradation between 200 and $350{ }^{\circ} \mathrm{C}$ refers to cellulose, since hemicellulose was partially removed, which proving good correlation between these two analysis methods. Agarwal and Lattimer [46] investigated the kinetics of pyrolysis for mixtures of several corn grass types with bituminous coal. They reported that the decomposition of hemicellulose initially occurred at $311.6{ }^{\circ} \mathrm{C}$, followed by the decomposition of cellulose around $365.4{ }^{\circ} \mathrm{C}$; lignin pyrolysis took place at a broader temperature range and did not have a specific peak value. Fang et al. [47] studied the combustion kinetics of four types of biomass: red pine (Pinus), corn straw, grass, and bamboo. They used thermogravimetric analyses (TGA) and identified three main degradation events: the evaporation of residual water from the sample (first event), removal and combustion of the volatile materials (second event), and all the carbonized material was, "char," (third event). These authors discovered that the second event occurred at a temperature range of $200-400{ }^{\circ} \mathrm{C}$. In general, this is attributed to the fact that hemicellulose degradation takes place in the range of $200-300{ }^{\circ} \mathrm{C}$; cellulose is more accentuated in the range of $300-400{ }^{\circ} \mathrm{C}$; and finally lignin degradation is strongest between 400 and $600{ }^{\circ} \mathrm{C}$. The main characteristic of this decomposition is that the speed in the second degradation event is significantly higher than in the third event. These authors attributed this to the fact that there is more volatile material than fixed carbon in the material. When all these degradation studies with different types of biomass are considered, it can be concluded that the present study had degradation ranges similar to those found by these authors. Carrier et al. [48] drawn good correlations between results of the levels of the main biomass components from chemical extraction and thermogravimetric analysis methods. The thermogravimetric method precisely determined values of the cellulose and hemicellulose levels of cellulose pulp. However, these authors also noted that the TGA method was not able to determine lignin levels; as there were significant deviations in the correlation curves.

\subsection{Determination of emissions factor using specific analyzers}

Table 3 shows results for $\mathrm{CO}_{2}, \mathrm{CO}$, $\mathrm{NO}$ and UHC emissions factors obtained in four tests carried out by burning samples of sugarcane straw and six tests with cellulignin from cane straw. These results were obtained by measuring average concentrations of the gases done with specific analyzers. Lopes and Carvalho [49] found emissions factors values of $1288 \pm 167 \mathrm{~g} \mathrm{~kg}^{-1}$ for $\mathrm{CO}_{2}$ and $28 \pm 3 \mathrm{~g} \mathrm{~kg}^{-1}$ for $\mathrm{CO}$ from burning sugarcane in laboratory experiments. The $\mathrm{CO}_{2}$ emission factor determined by these authors was similar to the estimate in this study, while the $\mathrm{CO}$ emission factor was lower.

Figures 3 through 8 present instantaneous mass consumption, gas concentration, temperature, and instantaneous emission factor data as functions of time during combustion for two tests, one with straw and the other with cellulignin. In the experiment with sugarcane straw (Figs. 3, 4, 5), a sample with initial mass of $0.319 \mathrm{~kg}$ was burned; the remaining mass was $0.049 \mathrm{~kg}$. The ignition process started in $13 \mathrm{~s}$ and extended to $33 \mathrm{~s}$; the test lasted for $10 \mathrm{~min}$ and $17 \mathrm{~s}$. In the experiment with cellulignin (Figs. 6, 7, 8), initial mass of the sample was $0.303 \mathrm{~kg}$ and the remaining mass was $0.066 \mathrm{~kg}$. The ignition process began at $15 \mathrm{~s}$ and continued until $43 \mathrm{~s}$; the test lasted 9 min and $49 \mathrm{~s}$.

In Fig. 3, the instantaneous burn rate in (a) was obtained as average values of the previous 20 measurements. The $\mathrm{CO}_{2}$ concentration and the temperature curves resemble the behavior of the instantaneous burn rate. The differences in the aspects of the curves for the two distinct fuels occurred due to differences of the path followed by the fire, which 
Table 3 Emissions factors, $\mathrm{EF}_{X}$, ( $\mathrm{g} \mathrm{kg}^{-1}$ of dry burned biomass) for sugarcane straw and straw cellulignin

\begin{tabular}{lllll}
\hline Sample & $\mathrm{CO}_{2}$ & $\mathrm{CO}$ & $\mathrm{NO}$ & $\mathrm{UHC}$ \\
\hline Sugarcane straw & $1316 \pm 83.6$ & $45.9 \pm 2.1$ & $1.01 \pm 0.09$ & $11.99 \pm 3.4$ \\
Cellulignin & $1275 \pm 105$ & $63.5 \pm 15.2$ & $0.73 \pm 0.16$ & $5.96 \pm 2.9$ \\
\hline
\end{tabular}
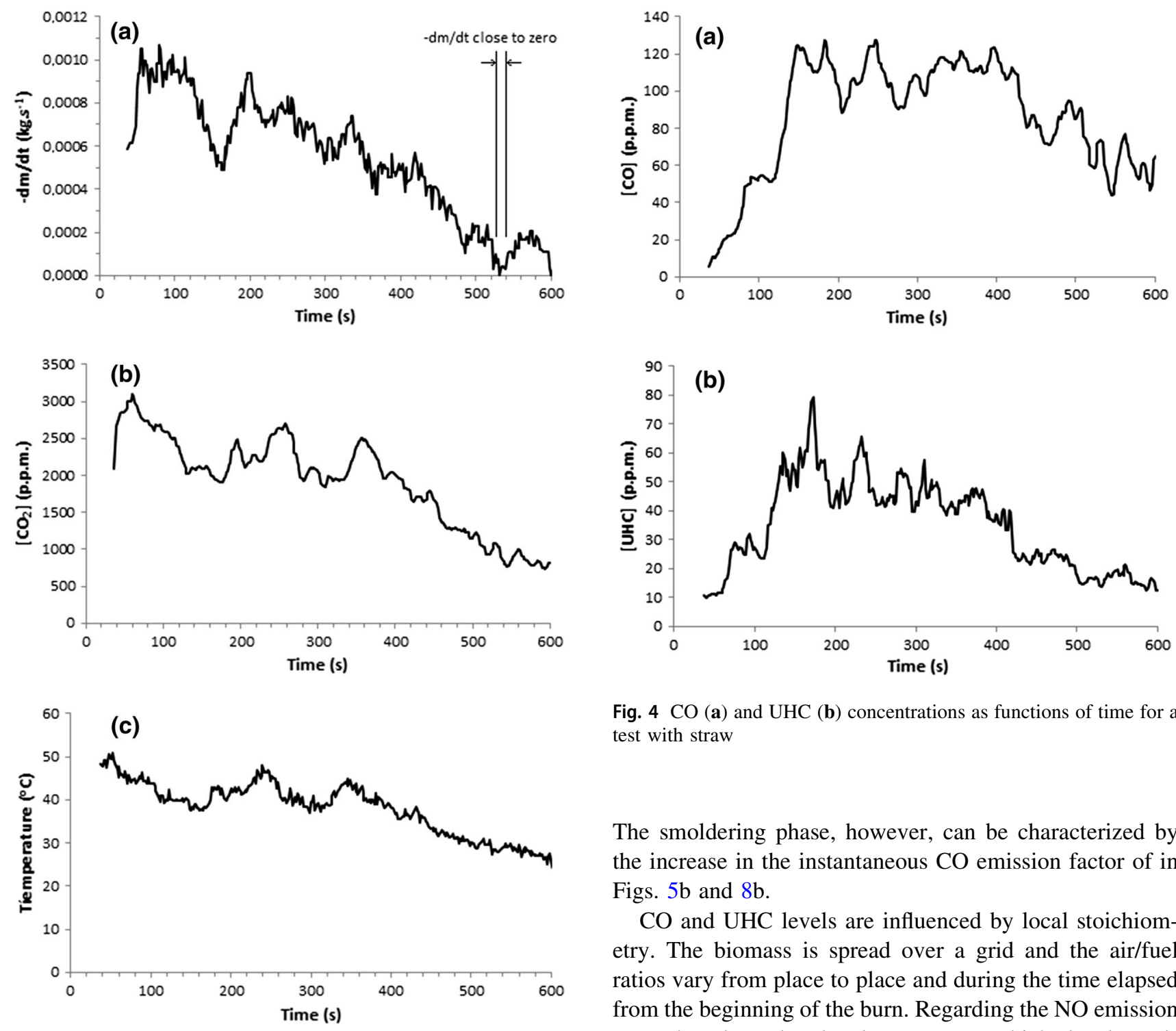

Fig. 4 CO (a) and UHC (b) concentrations as functions of time for a test with straw

The smoldering phase, however, can be characterized by the increase in the instantaneous $\mathrm{CO}$ emission factor of in Figs. $5 \mathrm{~b}$ and $8 \mathrm{~b}$.

$\mathrm{CO}$ and UHC levels are influenced by local stoichiometry. The biomass is spread over a grid and the air/fuel ratios vary from place to place and during the time elapsed from the beginning of the burn. Regarding the NO emission rates, they depend on local temperature which also depends

Fig. 3 Instantaneous burn rate (a), $\mathrm{CO}_{2}$ concentration (dry basis) (b), and chimney temperature (c) as functions of time for a test with straw

depends on the ignition procedures and on the way that fuel was packed on the grid.

Figures 4 and 7 present the $\mathrm{CO}$ and UHC concentrations as function of time. A certain resemblance between these concentrations is also noted. Increased concentrations at the end of the test were not observed for straw (Fig. 4), but occurring for cellulignin (Fig. 7). This is due to the very small burn rates for straw in the fourth quarter of the test. on local stoichiometry. NO concentrations were always lower than 10 p.p.m. and are not presented. The measurement error at this level of NO concentration is high.

Note that straw burned more easily. One of the factors that could have influenced the burning process is fuel moisture content. Cellulignin had content of $14.01 \%$, while straw had $9.54 \%$, so straw cellulignin with more humidity made burning more difficult. In the initial burning phase of both types of biomass, the behavior was similar, that is, there was greater loss of mass when there were more $\mathrm{CO}_{2}$ emissions. 

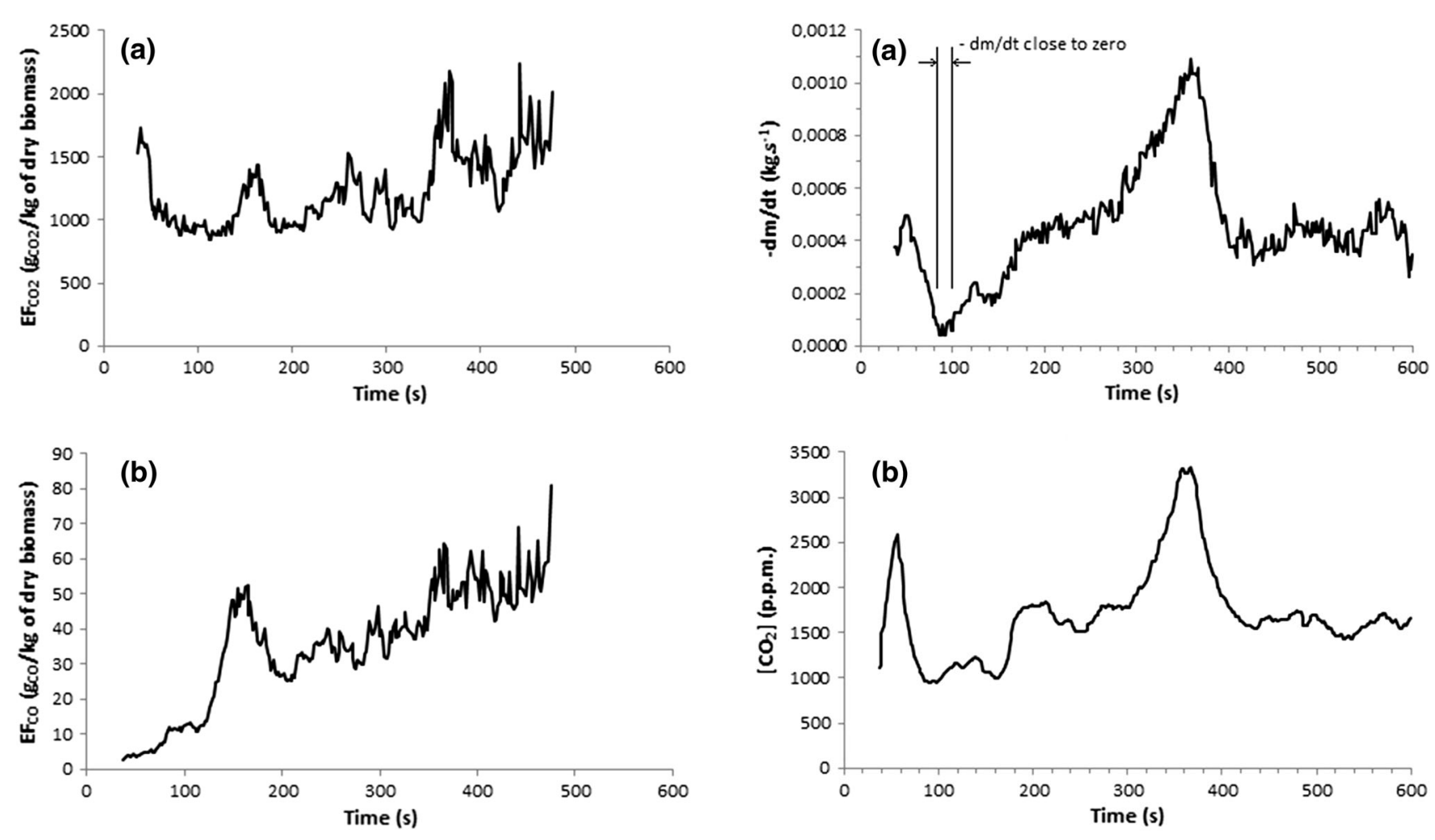

Fig. 5 Instantaneous emission factors for $\mathrm{CO}_{2}$ and $\mathrm{CO}$ as functions of time for a test with straw

The investigation about the burning of straw as a preharvest activity has been conducted in laboratory experiments, in which sugarcane made up part of the biomass [29]. Their objective was to determine pollutant emissions as it took place in the field. The present work focused on the use of sugarcane straw as a waste fuel; it was burned by itself without pieces of sugarcane. The emissions factor results from this study can be compared with those reported by França et al. [29], who found $1303 \pm 218$ for $\mathrm{CO}_{2}, 65 \pm 14$ for $\mathrm{CO}, 1.5 \pm 0.4$ for $\mathrm{NO}_{\mathrm{X}}$, and $16 \pm 6$ for $\mathrm{UHC}$, all values in $\mathrm{g} \mathrm{kg}_{\text {dryfuel }}^{-1}$. The values found by these authors were similar to those determined for the types of biomass in the present study. It should be noted that the values obtained by França et al. [29] are currently in use by IPCC (The Intergovernmental Panel on Climate Change).

Among the elements that are produced from combustion of cane straw, particulate matter is the most toxic for the population. It is mostly made up (94\%) of fine (diameter between 0.1 and $2.5 \mu \mathrm{m}$ ) and ultrafine (diameter less than $0.1 \mu \mathrm{m})$ particles. These particles are able to pass through the barriers of the respiratory system and reach the alveoli [50].

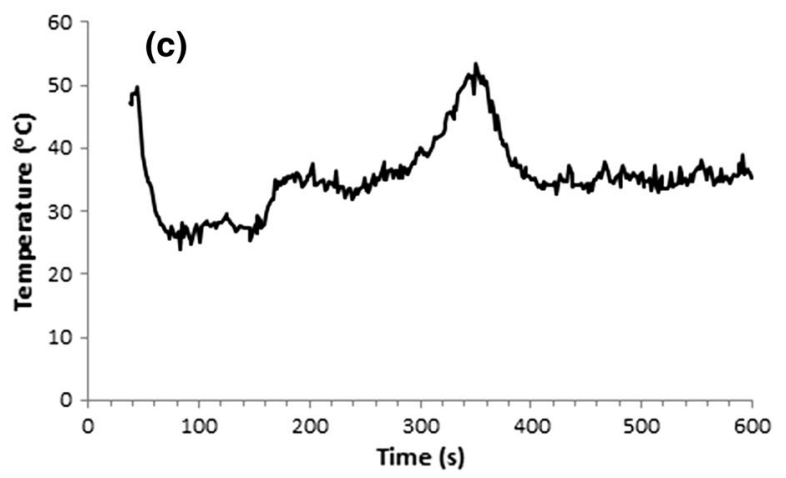

Fig. 6 Instantaneous burn rate (a), $\mathrm{CO}_{2}$ concentration (dry basis) (b), and chimney temperature (c) as functions of time for a test with cellulignin

\subsection{Theoretical and average experimental emission factors for $\mathrm{CO}_{2}$}

This section will discuss the differences between the theoretical emission factor (determined from the fuel elemental composition) and the experimental emission factor (determined during the tests). These differences occur mainly because of the fuel that remains partially unburned after the test (and after a real burn in the field). The derivation here is performed for straw; for cellulignin, the procedure is essentially similar.

The elemental composition of straw (given in Table 2), the combustion reaction for $100 \mathrm{~g}$ of fuel, with an 

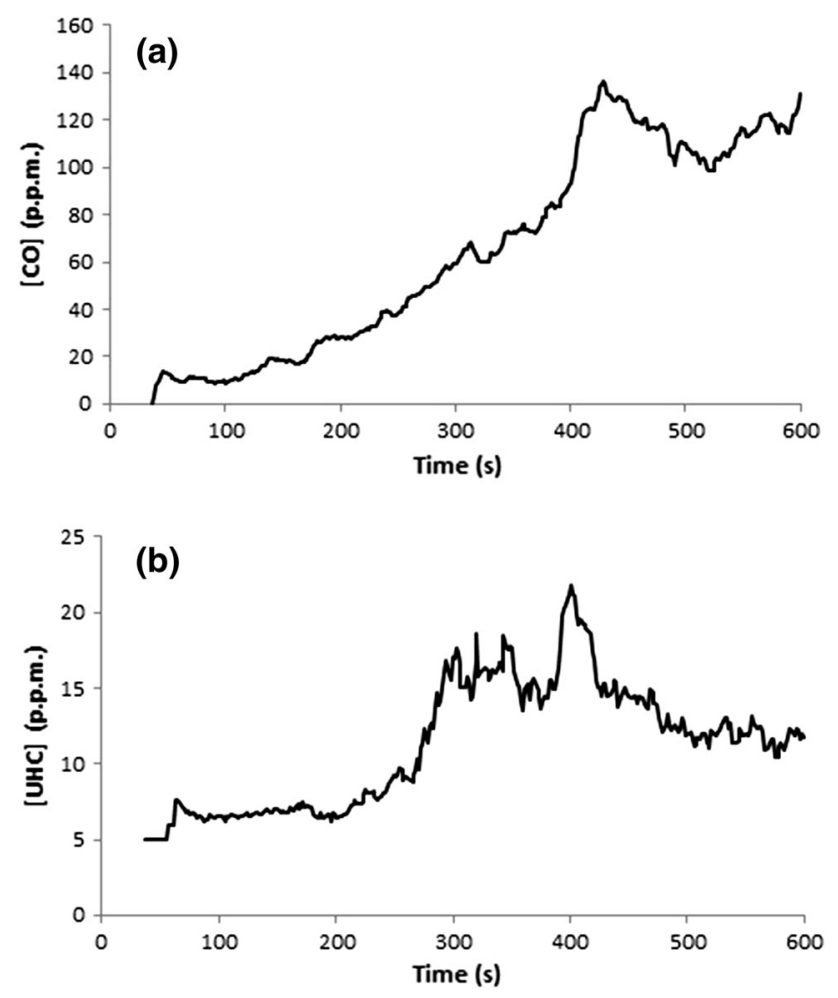

Fig. $7 \mathrm{CO}$ (a) and UHC (b) concentrations as functions of time for a test with cellulignin
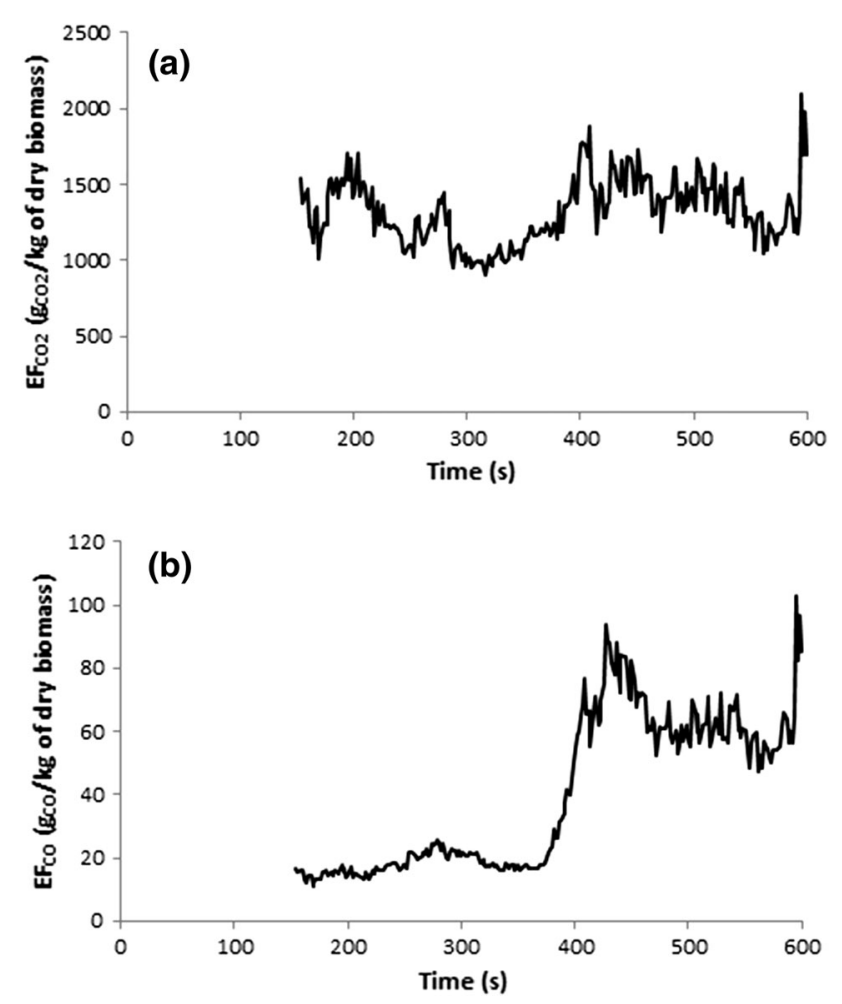

Fig. 8 Instantaneous emission factors for $\mathrm{CO}_{2}$ and $\mathrm{CO}$ as functions of time for a test with cellulignin assumption of no $\mathrm{CO}$ and other carbon products, is shown in Eq. (6).

$\frac{45.69}{12} \mathrm{C}+\frac{5.80}{1} \mathrm{H}+\frac{48.38}{16} \mathrm{O}+\frac{0.13}{14} \mathrm{~N}+$ Fuel moisture + Air $\rightarrow \frac{45.69}{12} \mathrm{CO}_{2}+$ Other combustion products,

and the theoretical $\mathrm{CO}_{2}$ emission factor for the cane straw is: $\mathrm{EF}_{\mathrm{CO}_{2}}=\frac{\frac{45.69}{12} 44}{0.100}=1675.3\left(\frac{\mathrm{g}_{\mathrm{CO}_{2}}}{\mathrm{~kg}_{\text {dryfuel }}}\right)$ for cane straw.

Similarly, the theoretical $\mathrm{CO}_{2}$ emission factor for the cellulignin: $\quad \mathrm{EF}_{\mathrm{CO}_{2}}=\frac{\frac{44.28}{12} 44}{0.100}=1623.6\left(\frac{\mathrm{g}_{\mathrm{CO}_{2}}}{\mathrm{~kg}_{\text {dryfuel }}}\right) \quad$ for cellulignin.

In the test with straw, the initial mass was $0.317 \mathrm{~kg}$, with $9.54 \%$ moisture content (i.e., initial dry mass = $0.28676 \mathrm{~kg}$ ). After the test, the residue was $0.049 \mathrm{~kg}$, which can be assumed to be completely dry. Considering that the carbon mass content of this residue is $Y$, then $0.049 / 0.28676=17.1 \%$ remains as $\mathrm{YC}$, where $Y$ can vary from 0 to 100 . The actual combustion reaction is then shown in Eq. 7:

$$
\begin{aligned}
& \frac{45.69}{12} \mathrm{C}+\frac{5.80}{1} \mathrm{H}+\frac{48.38}{16} \mathrm{O}+\frac{0.13}{14} \mathrm{~N}-\frac{0.171 Y}{12} \mathrm{C} \\
& + \text { Fuel moisture }+ \text { Air } \\
& \rightarrow \frac{45.69-0.171 Y}{12} \mathrm{CO}_{2}+\text { Other combustion products, }
\end{aligned}
$$

and, considering the value given in Table $2\left(1316 \mathrm{~g} \mathrm{~kg}^{-1}\right)$, the average experimental $\mathrm{CO}_{2}$ emission factor for straw is

$\mathrm{EF}_{\mathrm{CO}_{2}}=\frac{\frac{45.69-0.171 Y}{12} 44}{0.100-0.171}=1316\left(\frac{\mathrm{g}_{\mathrm{CO}_{2}}}{\mathrm{~kg}_{\text {dryfuel }}}\right)$.

With the above equation, the value of $Y$ is estimated to be $93.2 \%$, which means that the straw volatiles were easily released and most of the remains were pure carbon.

The same line of thought for cellulignin leads to an estimated $Y$ of $70.1 \%$. The difference in relation to that for straw can be regarded to the higher moisture content $(14 \%$ against $9.5 \%$ ) and to the initial size of the material for cellulignin.

The theoretical emission factors for the $\mathrm{CO}_{2}$ pollutant were 1675.3 and $1623.6 \mathrm{~g} \mathrm{~kg}^{-1}$ of dry-burning biomass for cane straw and cellulignin, respectively. While the experimental emission factors were 1316 and $1275 \mathrm{~g} \mathrm{~kg}^{-1}$ of dry-burning biomass for cane straw and cellulignin, respectively. For the two samples, the theoretical values found were $27.3 \%$ higher than the experimental ones. This is attributed to the fact that the fuel did not complete 
combustion in the experiment, so the fixed carbon was not totally transformed into $\mathrm{CO}_{2}$.

\section{Conclusion}

This study investigated the burning of lignocellulosic wastes to determine their emission factors. Cellulignin presented lower emission factors sugarcane straw. For cane straw, the differences between the theoretical and the experimental emission factors occurred mainly due to the fuel that remains partially unburned after the test. The theoretical emission factor determined for the $\mathrm{CO}_{2}$ through elemental composition data was $27.3 \%$ higher than the experimental value. This fact is attributed to incomplete burning.

The heating value of cellulignin was also determined and compared with that of cane straw; similar values were obtained for both materials (17.40 $\left.\mathrm{MJ} \mathrm{g}^{-1}\right)$. Interestingly, cellulignin did not totally burned, unlike the cane straw. The main components of the lignocellulosic materials (cellulose, lignin and hemicellulose) were determined by quantitative chemical analysis and thermal analysis. Comparing these two techniques, the traditional chemical analysis showed results more accurate and therefore more reliable. This behavior is due to the difficulty that the thermal analysis had in identifying the peaks of the biomass main components especially when it comes to lignin degradation. It is recommended that for future work, the main components of the biomass be separated and then used as the standard to better identify their respective peaks.

Acknowledgements The authors acknowledge the financial support by FAPESP (Fundação de Amparo à Pesquisa do Estado de São Paulo), Brazil, through processes 2013/27142-0 and 2013/04441-1.

\section{References}

1. Yan W, Perez S, Sheng K (2017) Upgrading fuel quality of moso bamboo via low temperature thermochemical treatments: dry torrefaction and hydrothermal carbonization. Fuel 196:473-480

2. Vassilev SV, Baxter D, Andersen LK, Vassileva CG (2010) Review article. An overview of the chemical composition of biomass. Fuel 89:913-933

3. Peduzzi E, Boissonnet G, Maréchal F (2016) Biomass modelling: estimating thermodynamic properties from the elemental composition. Fuel 181:207-217

4. Amaral SS, Carvalho JA Jr, Costa MAM, Soares Neto TG, Dellani R, Leite LHS (2014) Comparative study for hardwood and softwood forest biomass: characterization, combustion phases and gas and particulate matter. Biores Technol 164:55-63

5. Ren X, Sun R, Meng X, Vorobiev N, Schiemann M, Levendis YA (2017) Carbon, sulfur and nitrogen oxide emissions from combustion of pulverized raw and torrefied biomass. Fuel $188: 310-323$
6. CONAB-Companhia Nacional de Abastecimento. Acompanhamento da safra brasileira: Cana-de-açúcar. v.4-Safra 2017/2018, N.1. Primeiro Levantamento. Brasilia. 1-57, abril 2017. ISSN: 2318-7921

7. Santos FA, Queiroz JH, Colodette JL, Manfredi M, Queiroz MELR, Caldas CS, Soares FEF (2014) Otimização do pré-tratamento hidrotérmico da palha de cana-de-açúcar visando à produção de etanol celulósico. Quim Nova 37(1):56-62

8. Ripoli TCC, Molina WF Jr, Ripoli MLC (2000) Energy potential of sugarcane biomass in Brazil. Sci Agric 57(4):677-681

9. Carvalho DJ, Veiga JPS, Bizzo WA (2017) Analysis of energy consumption in three systems for collecting sugarcane straw for use in power generation. Energy 119:178-187

10. Ronquim CC (2010) Queimada na colheita de cana-de-açúcar: impactos ambientais, sociais e econômicos. Campinas: Embrapa Monitoramento por Satélite. Documentos 77. ISSN 0103-78110

11. CEMIG-Companhia Energética de Minas Gerais (2012) Alternativas Energéticas: uma visão CEMIG. CEMIG, Belo Horizonte

12. ANEEL-Agência Nacional de Energia Elétrica (2008) Atlas de energia elétrica do Brasil/Agência Nacional de Energia Elétrica. 3a. ed., Brasília: ANEEL. ISBN: 978-85-87491-10-7

13. Cherubini F (2010) The biorefinery concept: using biomass instead of oil for producing energy and chemicals. Energy Convers Manag 51:1412-1421

14. Dias MOS, Junqueira TL, Rossel CEV, Filho RM, Bonomi A (2013) Evaluation of process configurations for second generation integrated with first generation bioethanol production from sugarcane. Fuel Process Technol 109:84-89

15. Leal MRLV, Scarpare FV, Galdos MV, Oliveira COF (2013) Sugarcane straw availability, quality, recovery and energy use: a literature review. Biomass Bioenergy 53:11-19

16. Agostinho F, Ortega E (2013) Energetic-environmental assessment of a scenario for Brazilian cellulosic ethanol. J Clean Prod 47:474-489

17. Hernández-Pérez AF, Arruda PV, Felipe MGA (2016) Sugarcane straw as a feedstock for xylitol production by Candida guilliermondii FTI 20037. Braz J Microbiol 47:489-496

18. Hernández-Pérez AF, Costa IAL, Silva DDV, Dussán KJ, Villela TR, Canettieri EV, Carvalho JA Jr, Soares Neto TG, Felipe MGA (2016) Biochemical conversion of sugarcane straw hemicellulosic hydrolysate supplemented with co-substrates for xylitol production. Biores Technol 200:1085-1088

19. Oliveira FMV, Pinheiro IO, Souto-Maior AM, Martin C, Gonçalves AR, Rocha GJM (2013) Industrial-scale steam explosion pretreatment of sugarcane straw for enzymatic hydrolysis of cellulose for production of second generation ethanol and valueadded products. Biores Technol 130:168-173

20. Jutakanoke R, Leepipatpiboon N, Tolieng V, Kitpreechavanich V, Srinorakutara T, Akaracharanya A (2012) Sugarcane leaves: pretreatment and ethanol fermentation by Saccharomyces cerevisiae. Biomass Bioenergy 39:283-289

21. Moutta RO, Chandel AK, Rodrigues RCLB, Silva MB, Rocha GJM, Silva SS (2012) Statistical optimization of sugarcane leaves hydrolysis into simple sugars by dilute sulfuric acid catalyzed process. Sugar Technol 14:53-60

22. Sindhu R, Kuttiraja M, Binod P, Janu K, Sukumaran R, Pandey A (2011) Dilute acid pretreatment and enzymatic saccharification of sugarcane tops for bioethanol production. Biores Technol 102:10915-10921

23. Lago AC, Bonomi A, Cavalett O (2012) Sugarcane as a carbon source: the Brazilian case. Biomass Bioenergy 46:5-12

24. Seabra JEA, Tao L, Chuma HL, Macedo IC (2010) A technoeconomic evaluation of the effects of centralized cellulosic ethanol and co-products refinery options with sugarcane mill clustering. Biomass Bioenergy 34:1065-1078 
25. Demirbas A (1997) Calculation of higher heating values of biomass fuels. Fuel 76(5):431-434

26. Demirbas A (2001) Biomass resource facilities and biomass conversion processing for fuels and chemicals. Energy Convers Manag 42:1357-1378

27. Gouveia ER, Nascimento RT, Souto-Maior AM, Rocha GJM (2009) Validação de Metodologia para a caracterização química do bagaço de cana-de-açúcar. Quim Nova 32(6):1500-1503

28. Soares Neto TG, Carvalho JA Jr, Cortez EV, Azevedo RG, Oliveira RA, Fidalgo WRR, Santos JC (2011) Laboratory evaluation of amazon forest biomass burning emissions. Atmos Environ 45:7455-7461

29. França DA, Soares Neto TG, Longo KM, Carvalho JA (2012) Pre-harvest sugarcane burning: determination of emission factors through laboratory measurements. Atmosphere 3:164-180

30. Várhegyi G, Bobály B, Jakab E, Chen H (2011) Thermogravimetric study of biomass pyrolysis kinetics. A distributed activation energy model with prediction tests. Energy Fuels 25:24-32

31. Rocha GJM, Nascimento VM, Gonçalves AR, Silva VFN, Martín C (2015) Influence of mixed sugarcane bagasse samples evaluated by elemental and physical-chemical composition. Ind Crops Prod 64:52-58

32. Demirbas A (2004) Combustion characteristics of different biomass fuels. Prog Energy Combust Sci 30:219-230

33. Vamvuka D, Zografos D (2004) Predicting the behaviour of ash from agricultural wastes during combustion. Fuel 83:2051-2057

34. Telmo C, Lousada J (2011) The explained variation by lignina and extractive contentes on higher heating value of wood. Biomass Bioenergy 35(5):1663-1667

35. Ma T, Yang L, Yu H (2017) Catalytic characteristics of pyrolysis volatile matter from biomass/biomass components on a novel Nibased catalyst supported by iron slag. J Renew Sustain 9:063101

36. Kok MV, Özgür E (2013) Thermal analysis and kinetics of biomass samples. Fuel Process Technol 106:739-743

37. Chen D, Zheng Y, Zhu X (2013) In-depth investigation on the pyrolysis kinetics of raw biomass. Part I: kinetic analysis for the drying and devolatilization stages. Bioresource Technol $131: 40-46$

38. Anca-Couce A, Berger A, Zobel N (2014) How to determine consistent biomass pyrolysis kinetics in a parallel reaction scheme. Fuel 123:230-240

39. Jeong HM, Seo MW, Jeong SM, Na BK, Yoon SJ, Lee JG, Lee WJ (2014) Pyrolysis kinetics of coking coal mixed with biomass under non-isothermal and isothermal conditions. Bioresource Technol 155:442-445

40. Yousaf B, Liu G, Abbas Q, Wang R, Ali MU, Ullah H, Liu R, Zhou C (2017) Systematic investigation on combustion characteristics and emission-reduction mechanism of potentially toxic elements in biomass and biochar-coal co-combustion systems. Appl Energy 208:142-157

41. Ullah H, Liu G, Yousaf B, Ali MU, Abbas Q, Zhou C (2017) Combustion characteristics and retention-emission of selenium during co-firing of torrefied biomass and its blends with high ash coal. Bioresource Technol 245:73-80

42. Silva SS, Carvalho RR, Fonseca JLC, Garcia RB (1998) Extração e Caracterização de Xilanas de Sabugo s de Milho. Polímeros: Ciência e Tecnologia Abr/Jun, 25-33

43. Hon DNS, Shiraishi N (2001) Wood and cellulosic chemistry, 2nd Edn, Revised and expanded. Marcel Dekker, New York and Basel 914. ISBN 0-8247-0024-4

44. Alonso DM, Bond JQ, Dumesic JA (2010) Catalytic conversion of biomass to biofuels. Crit Rev Green Chem 12:1493-1513

45. Zhou H, Meng A, Long Y, Zhang Y (2013) The pyrolysis simulation of five biomass species by hemi-cellulose, celulose and lignina based on thermogravimetric curves. Thermochim Acta 566:36-43

46. Agarwal G, Lattimer B (2014) Physicochemical, kinetic and energetic investigation of coal-biomass mixture pyrolysis. Fuel Process Technol 124:174-187

47. Fang X, Jia L, Yin L (2013) A weighted average global process model based on two-stage kinetics scheme for biomass combustion. Biomass Bioenergy 48:43-50

48. Carrier M, Denux D, Loppinet-Serani A, Aymonier C (2011) Thermogravimetric analysis as a new method to determine the lignocellulosic composition of biomass. Biomass Bioenergy 35(1):298-307

49. Lopes MLA, Carvalho LRF (2009) Estimativas de emissão de gases provenientes da queima de cana-de-açúcar em escala regional. In: Proceedings of the $32^{\mathrm{a}}$ Reunião Anual da Sociedade Brasileira de Química (SBQ), Fortaleza, CE, Brazil, 30 May-2 June 2009

50. Arbex MA, Cançado JED, Pereira LAA, Braga ALF, Saldiva PHN (2004) Artigo de Revisão-Queima de biomassa e efeitos sobre a saúde. J Bras de Pneumol 30(2):158-175 